\title{
IAMJ
}

INTERNATIONAL

AYURVEDIC

MEDICAL JOURNAL

\section{A COMPARATIVE CLINICAL STUDY ON MATRA BASTI WITH BALA TAILA AND SAHACHARA TAILA}

\author{
Yadukrishnan V. $\mathbf{P}^{1}$, Praveen B. $\mathbf{S}^{2}$
}

${ }^{1}$ PG Scholar, ${ }^{2}$ Professor

Department of P.G Studies in Panchakarma, Alva's Ayurveda Medical College and Hospital, Moodubidire, Dakshina Karnataka, India

Corresponding Author: yadukrishnan10793@gmail.com

https://doi.org/10.46607/iamj0109112021

(Published Online: November 2021)

Open Access

(C) International Ayurvedic Medical Journal, India

Article Received: 02/10//2021 - Peer Reviewed: 27/10/2021 - Accepted for Publication: 29/10/2021

\section{Check for updates}

\begin{abstract}
Basti is said to be the best therapy for pacifying aggravated Vata Dosha. It is considered as Ardha Chikitsa due to the capacity to cure diseases of either Abhyantara, Bahya or Madhyama Roga Marga when used judiciously. It is broadly classified into Niruha, Anuvasana and Uttara Basti Anuvasana Basti believed to nourish the body and increase Bala (strength) and Varna (complexion). Matra Basti is a type of Anuvasana Basti in which the Sneha is administered in the lowest dosage. Gridhrasi is one among Vataja Nanatmaja Vikara characterised by Stabdhata (stiffness), Vedana (pain), Toda (pricking sensation) in the lumbar region radiating to the lower limb. Gridhrasi is of two types viz Vataja and Vata Kaphaja Gridhrasi. Vataja Gridhrasi is characterized by severe pain whereas, Vata Kaphaja Gridhrasi has symptoms viz Tandra (drowsiness), Gaurava (heaviness of body) and Aruchi (anorexia). Bala Taila contains Madhura Rasa, Snigdha, Vatahara, Balya, Brumhana properties. Sahachara Taila contains Madhura Tikta Rasa, Ushna Veerya and Vata-Kaphahara properties. This study was undertaken to compare the efficacy of Matra Basti with Bala Taila and Sahachara Taila in the management of Gridhrasi to ascertain a better modality. Statistical analysis showed that both groups showed good improvement in various parameters of Gridhrasi. When compared between the groups it revealed that there was not statistically difference except in S Lanss Pain Score ( $\mathrm{p}<0.05)$. Hence it can be concluded that both Bala Taila Matra Basti and Sahachara Taila
\end{abstract}


Matra Basti may be practiced in treating patients with Gridhrasi (Sciatica) to reduce both signs and symptoms successfully.

Keywords: Matra Basti, Gridhrasi, Bala Taila, Sahachara Taila

\section{INTRODUCTION}

Basti is said to be the best therapy for pacifying aggravated Vata Dosha. It is considered as Ardha Chikitsa due to the capacity to cure diseases of either Abhyantara, Bahya or Madhyama Roga Marga when used judiciously ${ }^{1}$. It is broadly classified into Niruha, Anuvasana and Uttara Basti. Anuvasana Basti is believed to nourish the body and increase Bala (strength) and Varna (complexion). Matra Basti is a type of Anuvasana Basti in which the Sneha is administered in the lowest dosage through anorectal route $^{2}$.

Gridhrasi is a clinical entity that produces intense pain and hampers day to day activities, affecting valuable hours. Gridhrasi is one among Vataja Nanatmaja Vikara characterized by Stabdhata (stiffness), Vedana (pain), Toda (pricking sensation) in Kati (waist) and radiating to Prishta (back), Uru (thigh), Janu (knee), Janga (calf) and Pada (foot). Gridhrasi is of two types viz Vataja and Vata Kaphaja Gridhrasi. Vataja Gridhrasi is characterized by severe pain whereas, Vata Kaphaja Gridhrasi has symptoms viz Tandra (drowsiness), Gaurava (heaviness of body) and Aruchi (anorexia) ${ }^{3,4}$. Sciatica refers to pain in the lumbar region which may radiate to the buttock, thigh, calf and foot, and pain is experienced along the sciatic nerve pathway. This term is more specifically used to denote nerve dysfunction caused by compression of one or more lumbar or sacral nerve roots from a spinal disc herniation ${ }^{5}$. Siravyada, Basti Karma and Agnikarma have extolled treatment in Gridhrasi and Sneha Pana, Abhyanga is the other choice of treatment ${ }^{6,7}$. Matra Basti is considered one of the best treatments for Vatavyadi due to fewer rituals and maximum benefits. Bala Taila, Sahachara Taila and Mulaka Taila are specifically indicated in the management of Gridhrasi ${ }^{8}$. Bala Taila (Sida cordifolia) possesses Madura Rasa, Sheeta Veerya, Balya, Kanthikara, Snigdha, Vatahara, Raktapittahara and Vrunahara properties 9 . Sahachara Taila consists of Mula, Patra and Shakha of Sahachara, Ksheera, sugar and Tila Taila which are indicated in all varieties of Vata diseases. Hence this study was conducted to evaluate the efficacy of Bala Taila Matra Basti and compare it with Sahachara Taila Matra Basi to ascertain the better modality in the management of Gridhrasi.

\section{Aim and Objectives}

1. To evaluate the efficacy of Bala taila Matra Bas$t i$ in the management of Gridhrasi (Sciatica).

2. To compare the efficacy of Sahachara Taila and Bala Taila Matra Basti in the management of Gridhrasi (Sciatica).

\section{Materials and Methods}

Literary Source: - All the Ayurveda and contemporary texts including websites about procedure, disease and drugs will be reviewed and documented for the intended study.

Sample Source: -Patients suffering from Gridhrasi (sciatica) was selected from the Panchakarma OPD and IPD of Alva's Ayurveda Medical College and Hospital, Moodbidri. Drug Source: - The drugs were collected from the local areas and markets after proper identification. Bala Taila and Sahachara Taila were prepared in Alva's Ayurveda Pharmacy, Mijar.

\section{METHOD OF COLLECTION OF DATA}

Study Design: - A Randomized Controlled singleblind clinical study.

Sample Size: - Group STMB - Sahachara Taila Matra Basti (Standard Control group) and Group BTMB - Bala Taila Matra Basti (Trial group) consist of 20 patients each.

1. Diagnostic Criteria: -Radiating pain starts from Sphik radiating to Kati, Prishta, Janu, Jangha, and Pada and positive SLR Test. 


\section{Inclusion Criteria}

1. Patients with symptoms of radiating pain from Sphik and Kati to Prishta, Uru. Janu, Janga and Pada.

2. Patients between age group 20-60 years of either sex.

3. Patients who were fit for Basti Karma.

\section{Exclusion Criteria}

1. Traumatic, Infective, Degenerative Conditions of Spine.

2. Congenital Spinal Anomalies.

3. Pregnant and Lactating Women.

4. Patients who are contraindicated for Basti karma

PROCEDURE: - 40 patients were assigned into two groups. Group STMB- Patients of this group were administered Matra Basti with Sahachara Taila in a dose of $72 \mathrm{ml}$ every day for 7 days. Group BTMBPatients of this group were administered Matra Basti with Bala Taila in the dose of $72 \mathrm{ml}$ every day for 7 days.

Poorva Karma: - Abhyanga and Nadi Sweda was done on the abdomen, buttock region, low back region, lower abdomen. The patient is offered Light Diet. The patient is asked to evacuate their bowel and bladder. The patient is made to lie in the left lateral position with the right leg flexed. Saindhava and Shatapushpa in 2 gms quantity each were added either to Bala Taila or to Sahachara Taila in respective groups.

Pradhana Karma: - The Tip of the catheter is smeared with oil. The anal orifice is lubricated with oil. The catheter is then introduced into the anal canal till 4 - 6 inches. When all the oil is pushed into the rectum, the catheter is gently pulled out.
Paschat Karma: - Sphik Thadana is done. The patient is made to lie in the supine position. The patient is made to raise the legs by flexing the hip 3-4 times. Nagara Dhanyaka Jala was advised later to sip by sip throughout the day.

OBSERVATION PERIOD: - On the first day before treatment and the last $\left(7^{\text {th }}\right)$ day after treatment. Both Groups was followed on the $14^{\text {th }}$ Day, $30^{\text {th }}$ Day, $45^{\text {th }}$ and $60^{\text {th }}$ day after the completion of the treatment protocol.

\section{ASSESSMENT CRITERIA}

Subjective Parameters: - Ruk (pain), Stamba (stiffness), Toda (pricking sensation), Tandra (weakness), Gaurava (heaviness), Aruchi (anorexia), Sciatica Frequency Index

Objective Parameters: - SLR test and 50 feet walk test

Statistical Method: -Average was found using mean and standard deviation. Pre-test and post-test data were compared using Wilcoxon Signed Rank Test. Comparison of two groups was done using Mann Whitney U Test.

Observation and Result: -In this study maximum number of incidence $(29.5 \%)$ was in the age groups $41-50$ and $51-60$ years and male $(61.3 \%)$. The majority of the patients had Vatakapha Prakruthi $(54.5 \%)$ and most of the patients were from middle socioeconomic status (61.3\%). Maximum patients had Madyama Vyayama Shakthi (47.8\%). The majority of the patients had chronicity of 0-6 months (31.8\%) followed by the chronicity of 13-19 months (22.7\%).

\section{RESULTS}


Table 1: Statistical analysis of Ruk.

\begin{tabular}{|c|c|c|c|c|c|c|c|c|c|}
\hline \multirow[t]{2}{*}{ Group } & \multicolumn{4}{|c|}{ Mean Score } & \multirow[b]{2}{*}{$\%$} & \multirow[b]{2}{*}{ S.D $( \pm)$} & \multirow[b]{2}{*}{ S.E $( \pm)$} & \multirow{2}{*}{$\begin{array}{l}\text { WSRT } \\
\text { value }\end{array}$} & \multirow{2}{*}{$\begin{array}{l}P \\
\text { value }\end{array}$} \\
\hline & BT & & & BT-AT & & & & & \\
\hline \multirow{5}{*}{ BTMB } & \multirow{5}{*}{2.20} & AT & 1.10 & 1.10 & $50.00 \%$ & 0.308 & 0.0688 & 9.59 & $<0.05$ \\
\hline & & AF1 & 1.10 & 1.10 & $50.00 \%$ & 0.308 & 0.0688 & 9.59 & $<0.05$ \\
\hline & & AF2 & 1.00 & 1.20 & $54.55 \%$ & 0.616 & 0.138 & 8.72 & $<0.05$ \\
\hline & & AF3 & 0.90 & 1.30 & $59.09 \%$ & 0.657 & 0.147 & 8.45 & $<0.05$ \\
\hline & & AF4 & 0.90 & 1.30 & $59.09 \%$ & 0.657 & 0.147 & 8.45 & $<0.05$ \\
\hline \multirow{5}{*}{ STMB } & \multirow{5}{*}{2.05} & AT & 0.95 & 1.10 & $53.66 \%$ & 0.308 & 0.0688 & 6.22 & $<0.05$ \\
\hline & & AF1 & 0.80 & 1.25 & $60.98 \%$ & 0.444 & 0.0993 & 8.54 & $<0.05$ \\
\hline & & AF2 & 0.80 & 1.25 & $60.98 \%$ & 0.444 & 0.0993 & 8.54 & $<0.05$ \\
\hline & & AF3 & 0.90 & 1.15 & $56.10 \%$ & 0.587 & 0.131 & 6.84 & $<0.05$ \\
\hline & & AF4 & 0.90 & 1.15 & $56.10 \%$ & 0.587 & 0.131 & 6.84 & $<0.05$ \\
\hline
\end{tabular}

The above table denotes that the effect of treatment on $R u k$ was significant $(\mathrm{P}<0.05)$ after treatment and after following up in both the groups.

Table 2: Statistical analysis of Stambha.

\begin{tabular}{|c|c|c|c|c|c|c|c|c|c|}
\hline \multirow[t]{2}{*}{ Group } & \multicolumn{4}{|c|}{ Mean Score } & \multirow[b]{2}{*}{$\%$} & \multirow[b]{2}{*}{ S.D $( \pm)$} & \multirow[b]{2}{*}{ S.E $( \pm)$} & \multirow{2}{*}{$\begin{array}{l}\text { WSRT } \\
\text { value }\end{array}$} & \multirow{2}{*}{$\begin{array}{l}P \\
\text { value }\end{array}$} \\
\hline & BT & & & BT-AT & & & & & \\
\hline \multirow{5}{*}{ BTMB } & \multirow{5}{*}{1.20} & AT & 0.20 & 1.00 & 83.33 & 0.459 & 0.103 & 171 & $<0.001$ \\
\hline & & AF1 & 0.10 & 1.10 & 91.67 & 0.553 & 0.124 & 171 & $<0.001$ \\
\hline & & AF2 & 0.00 & 1.20 & 100 & 0.616 & 0.138 & 171 & $<0.001$ \\
\hline & & AF3 & 0.00 & 1.20 & 100 & 0.616 & 0.138 & 171 & $<0.001$ \\
\hline & & AF4 & 0.00 & 1.20 & 100 & 0.616 & 0.138 & 171 & $<0.001$ \\
\hline \multirow{5}{*}{ STMB } & \multirow{5}{*}{1.45} & AT & 0.60 & 0.85 & 58.62 & 0.587 & 0.131 & 120 & $<0.001$ \\
\hline & & AF1 & 0.45 & 1.00 & 68.97 & 0.725 & 0.162 & 120 & $<0.001$ \\
\hline & & AF2 & 0.45 & 1.00 & 68.97 & 0.725 & 0.162 & 120 & $<0.001$ \\
\hline & & AF3 & 0.30 & 1.15 & 79.31 & 0.587 & 0.131 & 171 & $<0.001$ \\
\hline & & AF4 & 0.30 & 1.15 & 79.31 & 0.587 & 0.131 & 171 & $<0.001$ \\
\hline
\end{tabular}

The above table denotes that the effect of treatment on Stambha was highly significant $(\mathrm{P}<0.001)$ after treatment and after following up in both the groups.

Table 3: Statistical analysis of Toda.

\begin{tabular}{|c|c|c|c|c|c|c|c|c|c|}
\hline \multirow[t]{2}{*}{ Group } & \multicolumn{4}{|c|}{ Mean Score } & \multirow[b]{2}{*}{$\%$} & \multirow[b]{2}{*}{ S.D $( \pm)$} & \multirow[b]{2}{*}{ S.E $( \pm)$} & \multirow{2}{*}{$\begin{array}{l}\text { WSRT } \\
\text { value }\end{array}$} & \multirow{2}{*}{$\begin{array}{l}\mathbf{P} \\
\text { value }\end{array}$} \\
\hline & BT & & & BT-AT & & & & & \\
\hline \multirow{5}{*}{ ВTMB } & \multirow{5}{*}{1.60} & AT & 0.60 & 1.00 & 62.50 & 0.459 & 0.103 & 171 & $<0.001$ \\
\hline & & AF1 & 0.40 & 1.20 & 75.00 & 0.616 & 0.138 & 171 & $<0.001$ \\
\hline & & AF2 & 0.40 & 1.20 & 75.00 & 0.616 & 0.138 & 171 & $<0.001$ \\
\hline & & AF3 & 0.40 & 1.20 & 75.00 & 0.616 & 0.138 & 171 & $<0.001$ \\
\hline & & AF4 & 0.50 & 1.10 & 68.75 & 0.718 & 0.161 & 136 & $<0.001$ \\
\hline \multirow{5}{*}{ STMB } & \multirow{5}{*}{1.90} & AT & 0.95 & 0.95 & 50.00 & 0.945 & 0.211 & 66 & $<0.001$ \\
\hline & & AF1 & 0.70 & 1.20 & 63.16 & 1.005 & 0.225 & 105 & $<0.001$ \\
\hline & & AF2 & 0.60 & 1.30 & 68.42 & 0.923 & 0.206 & 136 & $<0.001$ \\
\hline & & AF3 & 0.60 & 1.30 & 68.42 & 0.923 & 0.202 & 136 & $<0.001$ \\
\hline & & AF4 & 0.75 & 1.15 & 60.53 & 1.040 & 0.233 & 91 & $<0.001$ \\
\hline
\end{tabular}

The above table denotes that the effect of treatment on Toda was highly significant $(\mathrm{P}<0.001)$ after treatment and after following up in both the groups. 
Table 4: Statistical analysis of Tandra.

\begin{tabular}{|c|c|c|c|c|c|c|c|c|c|}
\hline \multirow[t]{2}{*}{ Group } & \multicolumn{4}{|c|}{ Mean Score } & \multirow[b]{2}{*}{$\%$} & \multirow[b]{2}{*}{ S.D $( \pm)$} & \multirow[b]{2}{*}{ S.E $( \pm)$} & \multirow{2}{*}{$\begin{array}{l}\text { WSRT } \\
\text { value }\end{array}$} & \multirow{2}{*}{$\begin{array}{l}P \\
\text { value }\end{array}$} \\
\hline & BT & & & BT-AT & & & & & \\
\hline \multirow{5}{*}{ ВTMB } & \multirow{5}{*}{0.30} & AT & 0.10 & 0.20 & 66.67 & 0.410 & 0.0918 & 10 & $<0.05$ \\
\hline & & AF1 & 0.10 & 0.20 & 66.67 & 0.410 & 0.0918 & 10 & $<0.05$ \\
\hline & & AF2 & 0.00 & 0.30 & 100 & 0.470 & 0.105 & 21 & $<0.05$ \\
\hline & & AF3 & 0.00 & 0.30 & 100 & 0.470 & 0.105 & 21 & $<0.05$ \\
\hline & & AF4 & 0.00 & 0.30 & 100 & 0.470 & 0.105 & 21 & $<0.05$ \\
\hline \multirow{5}{*}{ STMB } & \multirow{5}{*}{0.35} & AT & 0.00 & 0.35 & 100 & 0.389 & 0.109 & 28 & $<0.05$ \\
\hline & & AF1 & 0.00 & 0.35 & 100 & 0.489 & 0.109 & 28 & $<0.05$ \\
\hline & & AF2 & 0.00 & 0.35 & 100 & 0.489 & 0.109 & 28 & $<0.05$ \\
\hline & & AF3 & 0.00 & 0.35 & 100 & 0.489 & 0.109 & 28 & $<0.05$ \\
\hline & & AF4 & 0.00 & 0.35 & 100 & 0.489 & 0.109 & 28 & $<0.05$ \\
\hline
\end{tabular}

The above table denotes that the effect of treatment on Tandra was significant $(\mathrm{P}<0.05)$ after treatment and after following up in both the groups.

Table 5: Statistical analysis of Gaurava.

\begin{tabular}{|c|c|c|c|c|c|c|c|c|c|}
\hline \multirow[t]{2}{*}{ Group } & \multicolumn{4}{|c|}{ Mean Score } & \multirow[b]{2}{*}{$\%$} & \multirow[b]{2}{*}{ S.D $( \pm)$} & \multirow[b]{2}{*}{ S.E $( \pm)$} & \multirow{2}{*}{$\begin{array}{l}\text { WSRT } \\
\text { value }\end{array}$} & \multirow{2}{*}{$\begin{array}{l}P \\
\text { value }\end{array}$} \\
\hline & BT & & & BT-AT & & & & & \\
\hline \multirow{5}{*}{ ВТМB } & \multirow{5}{*}{1.00} & AT & 0.50 & 0.50 & 50 & 0.688 & 0.154 & 36 & $<0.01$ \\
\hline & & AF1 & 0.40 & 0.60 & 60 & 0.681 & 0.152 & 55 & $<0.01$ \\
\hline & & AF2 & 0.30 & 0.70 & 70 & 0.923 & 0.206 & 55 & $<0.01$ \\
\hline & & AF3 & 0.30 & 0.70 & 70 & 0.923 & 0.206 & 55 & $<0.01$ \\
\hline & & AF4 & 0.30 & 0.70 & 70 & 0.923 & 0.206 & 55 & $<0.01$ \\
\hline \multirow{5}{*}{ STMB } & \multirow{5}{*}{1.10} & $\mathbf{A T}$ & 0.45 & 0.65 & 59.09 & 0.671 & 0.150 & 66 & $<0.001$ \\
\hline & & AF1 & 0.35 & 0.75 & 68.18 & 0.786 & 0.176 & 66 & $<0.001$ \\
\hline & & AF2 & 0.20 & 0.90 & 81.82 & 0.718 & 0.161 & 105 & $<0.001$ \\
\hline & & AF3 & 0.10 & 1.00 & 90.91 & 0.795 & 0.178 & 105 & $<0.001$ \\
\hline & & AF4 & 0.10 & 1.00 & 90.91 & 0.795 & 0.178 & 105 & $<0.001$ \\
\hline
\end{tabular}

The above table denotes that the effect of treatment on Gaurava was significant $(\mathrm{P}<0.01)$ after treatment and after following up in the group BTMB and highly significant $(\mathrm{p}<0.001)$ in group STMB.

Table 6: Statistical analysis of Aruchi.

\begin{tabular}{|c|c|c|c|c|c|c|c|c|c|}
\hline \multirow[t]{2}{*}{ Group } & \multicolumn{4}{|c|}{ Mean Score } & \multirow[b]{2}{*}{$\%$} & \multirow[b]{2}{*}{ S.D $( \pm)$} & \multirow[b]{2}{*}{ S.E $( \pm)$} & \multirow{2}{*}{$\begin{array}{l}\text { WSRT } \\
\text { value }\end{array}$} & \multirow{2}{*}{$\begin{array}{l}P \\
\text { value }\end{array}$} \\
\hline & BT & & & BT-AT & & & & & \\
\hline \multirow{5}{*}{ BTMB } & & AT & 0.05 & 0.15 & 75 & 0.366 & 0.0819 & 6.00 & $>0.05$ \\
\hline & & AF1 & 0.05 & 0.15 & 75 & 0.366 & 0.0819 & 6.00 & $>0.05$ \\
\hline & & AF2 & 0.05 & 0.15 & 75 & 0.366 & 0.0819 & 6.00 & $>0.05$ \\
\hline & & AF3 & 0.05 & 0.15 & 75 & 0.366 & 0.0819 & 6.00 & $>0.05$ \\
\hline & & AF4 & 0.05 & 0.15 & 75 & 0.366 & 0.0819 & 6.00 & $>0.05$ \\
\hline \multirow{5}{*}{ STMB } & & AT & 0.05 & 0.15 & 75 & 0.489 & 0.109 & 3.00 & $>0.05$ \\
\hline & & AF1 & 0.05 & 0.15 & 75 & 0.489 & 0.109 & 3.00 & $>0.05$ \\
\hline & & AF2 & 0.05 & 0.15 & 75 & 0.489 & 0.109 & 3.00 & $>0.05$ \\
\hline & & AF3 & 0.05 & 0.15 & 75 & 0.489 & 0.109 & 3.00 & $>0.05$ \\
\hline & & AF4 & 0.05 & 0.15 & 75 & 0.489 & 0.109 & 3.00 & $>0.05$ \\
\hline
\end{tabular}

The above table denotes that the effect of treatment on Aruchi was significant $(\mathrm{P}<0.05)$ after treatment and after following up in both the groups. 
Table 7: Statistical analysis of SLR Test

\begin{tabular}{|c|c|c|c|c|c|c|c|c|c|}
\hline \multirow[t]{2}{*}{ Group } & \multicolumn{4}{|c|}{ Mean Score } & \multirow[b]{2}{*}{$\%$} & \multirow[b]{2}{*}{ S.D $( \pm)$} & \multirow[b]{2}{*}{ S.E $( \pm)$} & \multirow{2}{*}{$\begin{array}{l}\text { WSRT } \\
\text { value }\end{array}$} & \multirow{2}{*}{$\begin{array}{l}P \\
\text { value }\end{array}$} \\
\hline & BT & & & BT-AT & & & & & \\
\hline \multirow{5}{*}{ BTMB } & \multirow{5}{*}{1.00} & AT & 0.70 & 0.30 & 30 & 0.470 & 0.105 & 21 & $<0.05$ \\
\hline & & AF1 & 0.40 & 0.60 & 60 & 0.503 & 0.112 & 78 & $<0.001$ \\
\hline & & AF2 & 0.40 & 0.60 & 60 & 0.503 & 0.122 & 78 & $<0.001$ \\
\hline & & AF3 & 0.40 & 0.60 & 60 & 0.503 & 0.122 & 78 & $<0.001$ \\
\hline & & AF4 & 0.40 & 0.60 & 60 & 0.503 & 0.122 & 78 & $<0.001$ \\
\hline \multirow{5}{*}{ STMB } & \multirow{5}{*}{1.0} & AT & 0.80 & 0.20 & 20 & 0.410 & 0.094 & 10 & $<0.05$ \\
\hline & & AF1 & 0.45 & 0.55 & 55 & 0.510 & 0.117 & 66 & $<0.001$ \\
\hline & & AF2 & 0.35 & 0.65 & 65 & 0.489 & 0.112 & 91 & $<0.001$ \\
\hline & & AF3 & 0.35 & 0.65 & 65 & 0.489 & 0.112 & 91 & $<0.001$ \\
\hline & & AF4 & 0.35 & 0.65 & 65 & 0.489 & 0.112 & 91 & $<0.001$ \\
\hline
\end{tabular}

The above table denotes that the effect of treatment on SLR Test was significant $(\mathrm{P}<0.05)$ after treatment and after following it showed highly significant $(\mathrm{P}<0.001)$ in both the groups.

Table 8: Statistical analysis of 50 Foot Walk Test

\begin{tabular}{|c|c|c|c|c|c|c|c|c|c|}
\hline \multirow[t]{2}{*}{ Group } & \multicolumn{4}{|c|}{ Mean Score } & \multirow[b]{2}{*}{$\%$} & \multirow[b]{2}{*}{ S.D $( \pm)$} & \multirow[b]{2}{*}{ S.E $( \pm)$} & \multirow{2}{*}{$\begin{array}{l}\text { WSRT } \\
\text { value }\end{array}$} & \multirow{2}{*}{$\begin{array}{l}P \\
\text { value }\end{array}$} \\
\hline & BT & & & BT-AT & & & & & \\
\hline \multirow{5}{*}{ BTMB } & \multirow{5}{*}{0.70} & $\mathbf{A T}$ & 0.10 & 0.60 & 85.71 & 0.503 & 0.115 & 78 & $<0.001$ \\
\hline & & AF1 & 0.00 & 0.70 & 100 & 0.657 & 0.151 & 78 & $<0.001$ \\
\hline & & AF2 & 0.00 & 0.70 & 100 & 0.657 & 0.151 & 78 & $<0.001$ \\
\hline & & AF3 & 0.00 & 0.70 & 100 & 0.657 & 0.151 & 78 & $<0.001$ \\
\hline & & AF4 & 0.00 & 0.70 & 100 & 0.657 & 0.151 & 78 & $<0.001$ \\
\hline \multirow{5}{*}{ STMB } & \multirow{5}{*}{1.05} & $\mathbf{A T}$ & 0.35 & 0.70 & 66.67 & 0.733 & 0.168 & 66 & $<0.001$ \\
\hline & & AF1 & 0.25 & 0.80 & 76.19 & 0.696 & 0.160 & 91 & $<0.001$ \\
\hline & & AF2 & 0.25 & 0.80 & 76.19 & 0.696 & 0.160 & 91 & $<0.001$ \\
\hline & & AF3 & 0.15 & 0.90 & 85.71 & 0.696 & 0.181 & 91 & $<0.001$ \\
\hline & & AF4 & 0.15 & 0.90 & 85.71 & 0.696 & 0.181 & 91 & $<0.001$ \\
\hline
\end{tabular}

The above table denotes that the effect of treatment on the 50 Foot Walk Test was highly significant $(\mathrm{P}<0.001)$ after treatment and after following up in both the groups.

Table 9: Statistical analysis of Sciatica Frequency Index.

\begin{tabular}{|c|c|c|c|c|c|c|c|c|c|}
\hline \multirow[t]{2}{*}{ Group } & \multicolumn{4}{|c|}{ Mean Score } & \multirow[b]{2}{*}{$\%$} & \multirow[b]{2}{*}{ S.D $( \pm)$} & \multirow[b]{2}{*}{ S.E $( \pm)$} & \multirow{2}{*}{$\begin{array}{l}\text { WSRT } \\
\text { value }\end{array}$} & \multirow{2}{*}{$\begin{array}{l}P \\
\text { value }\end{array}$} \\
\hline & BT & & & BT-AT & & & & & \\
\hline \multirow{5}{*}{ BTMB } & & AT & 5.00 & 6.20 & 57.69 & 1.576 & 0.352 & 210 & $<0.001$ \\
\hline & & AF1 & 4.45 & 6.75 & 57.69 & 1.860 & 0.416 & 210 & $<0.001$ \\
\hline & & AF2 & 3.85 & 7.35 & 69.23 & 1.981 & 0.443 & 210 & $<0.001$ \\
\hline & & AF3 & 3.70 & 7.50 & 65.38 & 1.960 & 0.438 & 210 & $<0.001$ \\
\hline & & AF4 & 3.70 & 7.50 & 65.38 & 1.960 & 0.438 & 210 & $<0.001$ \\
\hline \multirow{5}{*}{ STMB } & & AT & 5.15 & 6.10 & 52.73 & 1.683 & 0.376 & 210 & $<0.001$ \\
\hline & & AF1 & 3.85 & 7.40 & 60.00 & 2.479 & 0.554 & 210 & $<0.001$ \\
\hline & & AF2 & 3.40 & 7.85 & 63.64 & 2.796 & 0.625 & 210 & $<0.001$ \\
\hline & & AF3 & 3.25 & 8.00 & 60.00 & 3.044 & 0.681 & 210 & $<0.001$ \\
\hline & & AF4 & 3.10 & 8.15 & 54.55 & 3.345 & 0.748 & 210 & $<0.001$ \\
\hline
\end{tabular}

The above table denotes that the effect of treatment on the Sciatica Frequency Index was highly significant $(\mathrm{P}<0.001)$ after treatment and after following up in both the groups. 
Table 10: Statistical analysis of S Lanss Pain Score.

\begin{tabular}{|c|c|c|c|c|c|c|c|c|c|}
\hline \multirow[t]{2}{*}{ Group } & \multicolumn{4}{|c|}{ Mean Score } & \multirow[b]{2}{*}{$\%$} & \multirow[b]{2}{*}{ S.D $( \pm)$} & \multirow[b]{2}{*}{ S.E $( \pm)$} & \multirow{2}{*}{$\begin{array}{l}\text { WSRT } \\
\text { value }\end{array}$} & \multirow{2}{*}{$\begin{array}{c}P \\
\text { value }\end{array}$} \\
\hline & BT & & & BT-AT & & & & & \\
\hline \multirow{5}{*}{ ВТMB } & & AT & 7.90 & 5.90 & 42.75 & 1.917 & 0.440 & 210 & $<0.001$ \\
\hline & & AF1 & 7.30 & 6.50 & 47.10 & 1.606 & 0.368 & 210 & $<0.001$ \\
\hline & & AF2 & 6.80 & 7.00 & 50.72 & 2.340 & 0.537 & 210 & $<0.001$ \\
\hline & & AF3 & 6.30 & 7.50 & 54.35 & 2.115 & 0.485 & 210 & $<0.001$ \\
\hline & & AF4 & 6.30 & 7.50 & 54.35 & 2.115 & 0.485 & 210 & $<0.001$ \\
\hline \multirow{5}{*}{ STMB } & & AT & 9.70 & 6.40 & 39.75 & 2.210 & 0.507 & 210 & $<0.001$ \\
\hline & & AF1 & 7.25 & 8.85 & 54.97 & 2.540 & 0.583 & 210 & $<0.001$ \\
\hline & & AF2 & 6.75 & 9.35 & 58.07 & 3.360 & 0.771 & 210 & $<0.001$ \\
\hline & & AF3 & 6.55 & 9.55 & 59.32 & 3.517 & 0.807 & 210 & $<0.001$ \\
\hline & & AF4 & 6.25 & 9.85 & 61.18 & 3.843 & 0.882 & 210 & $<0.001$ \\
\hline
\end{tabular}

The above table denotes that the effect of treatment on S Lanss Pain Score was highly significant $(\mathrm{P}<0.001)$ after treatment and after following up in both the groups.

Table 11: Comparative Effect of Group BTMB and Group STMB.

\begin{tabular}{|c|c|c|c|c|}
\hline \multirow[t]{2}{*}{ FETURS } & \multicolumn{2}{|c|}{ MEDIAN SCOR } & \multirow{2}{*}{$\begin{array}{l}\text { MWUT } \\
\text { value }\end{array}$} & \multirow{2}{*}{$\begin{array}{l}P \\
\text { value }\end{array}$} \\
\hline & Group BTMB & Group STMB & & \\
\hline Ruk & 1 & 1 & 410 & $>0.05$ \\
\hline Sthamba & 1 & 1 & 437 & $>0.05$ \\
\hline Toda & 1 & 1 & 419 & $>0.05$ \\
\hline Tandra & 1 & 1 & 390 & $>0.05$ \\
\hline Gaurava & 0 & 1 & 389 & $>0.05$ \\
\hline Aruchi & 0 & 0 & 410 & $>0.05$ \\
\hline SLR test & 0 & 0 & 430 & $>0.05$ \\
\hline 50 Foot walk test & 1 & 1 & 402 & $>0.05$ \\
\hline Sciatica Frequency index & 6 & 6.5 & 414 & $>0.05$ \\
\hline S Lanns pain score & 5 & 7 & 346 & $>0.05$ \\
\hline
\end{tabular}

On comparing the two groups there is no significant difference in the efficacy of treatment seen after treatment and first, follow up and in $2^{\text {nd }}, 3^{\text {rd }}$ and $4^{\text {th }}$ follow up showed the significant result in Group STMB at $\mathrm{P}<0.05$.

\section{DISCUSSION}

Gridhrasi is one among Vataja Nanatmaja Vikara characterised by Stabdhata (stiffness), Vedana (pain), Toda (pricking sensation) in the lumbar region radiating to the lower limb. Basti is said to be the best therapy for pacifying aggravated Vata Dosha. In this study maximum number of incidences $(29.5 \%)$ was in the age groups of 41-50 and 51-60 years. This may be occurred due to the progressive Vata Prakopa that occurs in this range of Vaya ${ }^{10}$. In this study maximum number of patients were found to be Male $(62.5 \%)$. This could be due to a lower incidence of degenerative changes in premenopausal women ${ }^{11}$. The majority of the patient were belonging to the middle class (62.5\%). This might be due to the demographic fact. Most of the patients were shown Vatakapha Prakrthi
(55) $\%$ and $35 \%$ of the patients showed Vatapitta Prakrthi. This may suggest that Vata Prakrthi individuals are more prone to Vataja disease. Most of the patients were shown Madyama Vyayama Shakthi ie. $47.5 \%$. This observation shows that the disease condition hampers the daily activity to an extent. The Bala Taila process of Madhura Rasa, Snigdha, Pichila Guna, Vatahara, Balya, Brmhana and Vrsya properties. The researchers showed the pharmacological properties of Sida cardifolia related to Gridhrasi includes Analgesic, Anti-inflammatory and Antioxidant $^{12}$. The Sahachara Taila process of Madhura Rasa, Ushna Veerya, Vatahara, Balya and Brmhana properties. Research on Baeleria prionitis shows Analgesic, Anti-inflammatory, Antioxidant and Antinociceptive activities ${ }^{13}$. Bala Taila and Shachara 
Taila have analgesic and antioxidant activity which helps to reduce the pain. Sahachara Taila showed a significant effect in the $2^{\text {nd }}, 3^{\text {rd }}$ and $4^{\text {th }}$ follow up of $\mathrm{S}$ Lanss Pain Score this might be because of the antiinflammatory and anti-nociceptive activity of Sahachara Taila. Both the Taila were having the base of Tila Taila, which consist of Vedhanasthapana action and the pharmacologically which consist of antioxidant, anti-inflammatory, analgesic, anti-cardio, antipyretic effect as well as anti-nociceptive action. Bala Taila and Sahachara Taila have Madhura Rasa, Snigdha Guna and Vatahara property which helps to reduce Sthamba. Both Bala Taila and Sahachara Taila consist of Balya and Brihmana property, which helps to reduce the weakness of the patients. The Bala Taila consist of Laghu Guna which helps to reduce the Gaurava. Sahachara Taila consists of Vatakaphahara, Laghu Guna, and Ushna Veerya properties which helps to reduce the Gaurava. Both Bala Taila and Sahachara Taila consist of Balya and Brihmana property which helps to give better effect in the 50 Foot Walk Test. Were in Vatakaphaja Gridhrasi consist of Tandra, Gaurava, Aruchi features in addition to Ruk, Toda, and Sthambha. Bala Taila consist of Laghu Guna and Sahachara Taila consist of Vatakapha Hara property, Laghu Guna and Ushna Veerya which helps to control the symptoms of Vatakaphaja Gridhrasi. The treatment Matra Basti, which acts directly on Vata Sthana that is Pakwashaya, again helps to manage vitiated Vata Dhosha thereby controlling the symptoms, produced.

\section{CONCLUSION}

It can be concluded that there is a significant effect of both Bala Taila Matra Basti and Sahachara Taila Matra Basti in Gridhrasi. Both the treatments may be considered in treating patients with Gridhrasi to reduce both signs and symptoms successfully.

\section{REFERENCES}

1. Agnivesha, Charaka Samhitha with Ayurveda Deepika commentary of Chakrapani Datta, edited Vaidya Jadavji Trikamji Acharya, published by Chaukhamba Surabharati Prakashan Varanasi; 2012, Chikitsa sthana.28:46 - 47, pp.787.
2. Agnivesha, Charaka Samhitha with Ayurveda Deepika commentary of Chakrapani Datta, edited Vaidya Jadavji Trikamji Acharya, published by Chaukhamba Surabharati Prakashan Varanasi, reprinted (2015), Siddhi Sthana 1:29, pp. 682.

3. Madhavanidana, by Madhavakara with the commentary of Madhukosha by Vijayarakshithita and Srikanthadatta and with extracts from Atankadarpana by Vachaspativaidya, edited Vaidyajadavajitricumjiacharyachaukamabaorientalia, reprint 2010 , vatavyadhi 22:55, pp. 175 .

4. Agnivesha, Charaka Samhita, Elaborated by Charaka and Dradabala, with the Ayurvedadipika Commentary edited by Vaidya Jadavaji Trikamji Acharya, Chaukhamba prakashana, reprint 2011 Chikitsa Sthana28:57, pp. 6719.

5. Davidson, Principles, and Practice of Medicine, edited by John A.A. Hunter 20th edition, Neurological Disease, Disordersn of the spine and spinal cord, pp. 1242

6. Agnivesha, Charaka Samhitha with Ayurveda Deepika commentary of Chakrapani Datta, edited Vaidya Jadavji Trikamji Acharya, published by Chaukhamba Surabharati Prakashan Varanasi, reprinted (2015), Chikitsa Sthana 28:101, pp. 621.

7. Atreya, Bhela Samhitha with the English translation of K.H. Krishnamurthy, edited P.V. Sharma published by Chaukhambha Visvabharati, Varanasi, reprint 2008, Chikitsasthana 24:45, pp. 454.

8. Atreya, Bhela Samhitha with the English translation of K.H. Krishnamurthy, edited P.V. Sharma published by Chaukhambha Visvabharati, Varanasi, reprint 2008, Chikitsasthana 24:44, pp. 454.

9. Bhavamisra, Bhavaprakasha Nighantu, of K.C. Chunekar, edited by G.S. Pandey, published by Chaukhambha Bharati Academy, Varanasi, reprint 2006, $142-143$, pp. 366.

10. Vagbhata. Ashtanga Hridaya with commentaries Sarvanga Sundari of Arunadhatta and Ayurveda Rasayana of Hemadri Chaukambha. Varanasi; Sanskrit Sansthan; 2012. Sutra Sthana 1:8, pp.7.

11. https://www.ncbi.nlm.nih.gov/pmc/articles/PMC4858 $456 /$

12. https://www.ncbi.nlm.nih.gov/pmc/articles/PMC2865 797/

13. https://www.wjpr.net/download/article/1521109341.p df

\section{Source of Support: Nil \\ Conflict of Interest: None Declared}

How to cite this URL: Yadukrishnan V. P Praveen B.S: A Comparative Clinical Study On Matra Basti With Bala Taila And Sahachara Taila. International Ayurvedic Medical Journal \{online\} 2021 \{cited November 2021\} Available from: http://www.iamj.in/posts/images/upload/2644_2651.pdf 